BMJ Open

Sport \&

Exercise

Medicine

\title{
'\#BeTheChange': the responsibility of sports medicine in protecting athletes from harassment and abuse in sport
}

\author{
Margo Lynn Mountjoy (D) , ${ }^{1}$ Evert Verhagen (1D ${ }^{2}$
}

To cite: Mountjoy ML, Verhagen $\mathrm{E}$. '\#BeTheChange': the responsibility of sports medicine in protecting athletes from harassment and abuse in sport. BMJ Open Sport \& Exercise Medicine 2022;8:e001303. doi:10.1136/ bmjsem-2021-001303

Accepted 11 February 2022

Check for updates

(C) Author(s) (or their employer(s)) 2022. Re-use permitted under CC BY-NC. No commercial re-use. See rights and permissions. Published by BMJ.

${ }^{1}$ Family Medicine, McMaster University, Hamilton, Ontario Canada

${ }^{2}$ Department of Public and Occupational Health, EMGO, Amsterdam UMC Locatie VUmc, Amsterdam, The Netherlands

Correspondence to Dr Margo Lynn Mountjoy; mountjm@mcmaster.ca
Mahatma Gandhi was an Indian lawyer who became famous for employing non-violent measures to influence change to improve civil rights and liberties. 'Be the change you wish to see in the world' is one of Gandhi's quotes that exemplifies his approach to inspiring change in attitude and behaviour at the individual level. As sports medicine physicians, we should be motivated to action by these words while sport faces one of the most severe threats to athlete health and wellbeing; harassment and abuse.

Safe sport is defined as an athletic environment that is respectful, equitable and free from any form of harassment and abuse. There are four forms of harassment and abuse in sport: psychological, physical, sexual, and neglect. Harassment and abuse occur across all sports, and at all levels, with increasing risk at the elite level, for child athletes, athletes with a disability and those who identify as LGBTQ+ (lesbian/gay/bisexual/trans-sexual/ queer+). ${ }^{1}$ Prominent cases of harassment and abuse worldwide have shocked sports politicians, the media and advocacy groups to action. Some of the many examples include (i) the Human Rights Watch report on the practice of Taibatsu (corporal punishment) in youth sport in Japan²; (ii) Operation Hydrant (multi-divisional police investigation) in British football involving 849 victims from 340 football clubs, and 300 alleged suspects $^{3}$; (iii) allegations of systemic sexual abuse in women's basketball in Mali, Africa ${ }^{4}$ and (iv) the sexual abuse of 256 gymnasts by Dr Larry Nassar in the USA. ${ }^{5}$

The prevalence of harassment and abuse is difficult to quantify due to severe underreporting. However, several studies have revealed alarming results that we cannot neglect. For example, a survey including 6124 youth athletes (aged 18-22 years) in Great Britain showed a prevalence of $29 \%$ for sexual harassment and $3 \%$ for sexual abuse prior to the age of $16 .{ }^{6}$ Another study showed that $75 \%$ of athletes experienced psychological abuse and 25\% physical abuse before they turned 16 years. $^{7}$ A retrospective survey of 4000 athletes in the Netherlands and Belgium identified that during their youth athletic career, $44 \%$ had experienced harassment and abuse (14\% sexual, $11 \%$ physical, $33 \%$ psychological abuse) ${ }^{8}$

\section{HARASSMENT AND ABUSE IMPACT ATHLETE HEALTH}

The impacts of harassment and abuse on athletes' health and well-being are extensive, can be severe and last long after the abuse has ended. Figure 1 illustrates the forms, the mechanisms and the impact of harassment and abuse on the athlete.

The mental health impacts of harassment and abuse vary depending on the type of abuse, the duration and the circumstances. Reported mental health symptoms resulting from harassment and abuse include avoidance, dependence, low self-esteem, low self-worth and poor concentration. The mental health disorders attributed to experiencing harassment and abuse are depression, anxiety, posttraumatic stress disorder, disordered eating, eating disorders, substance misuse, self-harm, and even suicide. ${ }^{9}$

The physical impacts of abuse include injuries, self-harm, psychosomatic illnesses, unwanted pregnancies and sexually transmitted infections. Harassment and abuse can negatively affect athletic performance and cause premature drop-out from the sport. Victims of harassment and abuse have been shown to have an increased willingness to cheat in sport and participate in doping. ${ }^{1}$

\section{WHAT IS THE RESPONSIBILITY OF SPORTS MEDICINE PHYSICIANS?}

Various professional guidelines regulate our responsibilities and actions towards athlete health and protection. One such ethical framework is the Declaration of 


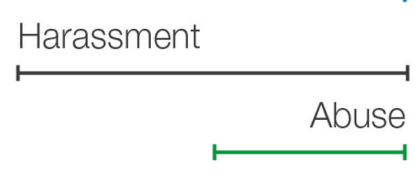

\begin{tabular}{|c|c|c|}
\hline Cultural Context & $\begin{array}{l}\text { Types of } \\
\text { non-accidental } \\
\text { violence }\end{array}$ & Impacts (Indicative) \\
\hline $\begin{array}{l}\text { Based on power } \\
\text { differentials in: } \\
\text { Sex } \\
\text { Gender } \\
\text { Race } \\
\text { Ethnicity } \\
\text { Indigeneity } \\
\text { (Dis)ability } \\
\text { Age } \\
\text { Athletic Ability } \\
\text { Athletic Longevity } \\
\text { Faith } \\
\text { Socio-economic/ } \\
\text { Financial status } \\
\text {...or combinations } \\
\text { of these }\end{array}$ & $\begin{array}{l}\text { Psychological } \\
+ \\
\text { Physical } \\
\text { Sexual } \\
\text { Neglect } \\
\text { Mechanisms: } \\
\text { Contact } \\
\text { Non-contact/verbal } \\
\text { Cyber } \\
\text { Negligence } \\
\text { Bullying } \\
\text { Hazing }\end{array}$ & $\begin{array}{l}\text { Athletic Impacts } \\
\text { Physical (e.g. illness and injuries, performance loss, } \\
\text { disordered eating/EDs, PTSD, self-harm, STIs) } \\
\text { Cognitive (e.g. low self-esteem) } \\
\text { Emotional (e.g. volatile mood states) } \\
\text { Behavioural (e.g. drop out, more likely to cheat) } \\
\text { Mental health (e.g. anxiety, depression, suicide) } \\
\text { Relationship (e.g. social exclusion/marginality) } \\
\text { Economic losses } \\
\text { Organisational Impacts } \\
\text { Reputational damage } \\
\text { Loss of players and fans } \\
\text { Loss of sponsorship } \\
\text { Reduced medal tally } \\
\text { Reduced public confidence } \\
\text { Loss of trust } \\
\text { Asset depreciation }\end{array}$ \\
\hline
\end{tabular}

Further details and examples of what can constitute harassment and abuse can be found in the IOC Consensus Statement: Harassment and Abuse in Sport (2016).

Figure 1 The International Olympic Committee model demonstrates the continuum of harassment and abuse in sport and the resulting athlete and organisational impacts. ${ }^{1}$ EDs, Eating Disorders; PTSD, Post Traumatic Stress Disorder; STI, Sexually Transmitted Infections.

Geneva adopted by the World Medical Association, which states, 'As a member of the medical profession, the health and well-being of my patient will be my first consideration'. ${ }^{10}$ Sports medicine physicians also have an overarching ethical code of conduct developed by the International Olympic Committee, which outlines athletes' rights as patients and provides guidelines for the ethical behaviour of sports medicine physicians within the context of elite sport. The Olympic Movement Medical Code (2016) states:

The Olympic movement ... encourages all stakeholders to take measures to ensure that sport is practised to minimise harm to the health of the athletes ... to protect the health of participants by minimising the risks of physical injury, illness and psychological harm ... [2.1.4] For the benefit of all concerned, measures to safeguard the health of the athletes and to minimise the risks of physical injury and psychological harm. ${ }^{11}$

From the above, we can only conclude that it is our strong obligation as sports medicine physicians to support the health and well-being of our athletes as patients in our care, and to consider the significant health impacts of harassment and abuse, the prevention of harassment and abuse, and understand that the support of athlete victims is our individual and collective responsibility.

\section{\#BETHECHANGE: THE CALL TO ACTION}

Sports medicine physicians should have the clinical competence to recognise the signs and symptoms of abuse, to manage disclosures of athlete allegations, to be knowledgeable of reporting obligations and mechanisms, and to support the athlete in their recovery as a member of a multidisciplinary team (ie, sports medicine, 


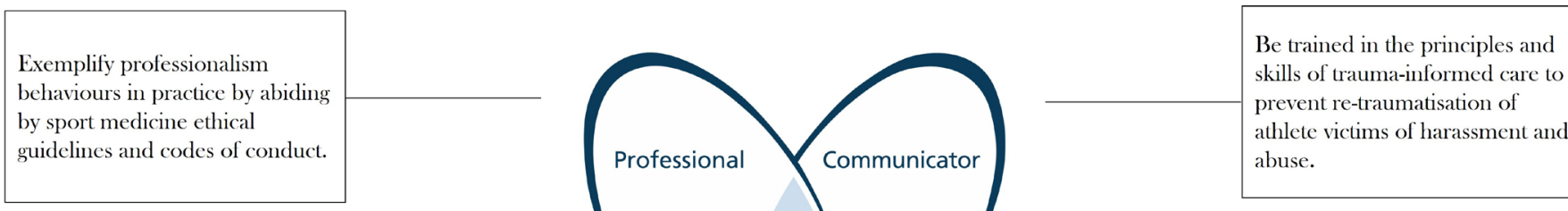

Educate athletes, coaches, the entourage, and sports leadership about the health impacts of harassment and abuse, to raise awareness and encourage reporting.

Instrumental in lobbying for the development and implementation of robust safeguarding policies and procedures in all sports organisations.

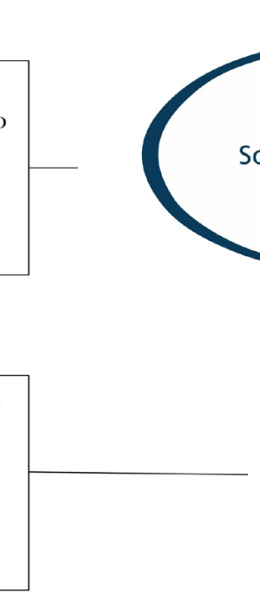

Figure 2 A framework to guide sports medicine physician's behaviours and actions modified from the CanMEDS Framework. ${ }^{15}$ Copyright 2015 The Royal College of Physicians and Surgeons of Canada. https://wwwroyalcollegeca/rcsite/ canmeds/canmeds-framework-e. Reproduced with permission.

sports psychiatry, specialist as required). ${ }^{12}$ Sports medicine physicians should also be trained in the principles and skills of trauma-informed care to prevent re-traumatisation of athlete victims of harassment and abuse. ${ }^{13}$ These core clinical competencies should be embedded in the sports medicine fellowship training curriculum. ${ }^{14}$ Finally, we must understand and acknowledge that sports medicine physicians cannot bring effective change if the ecosystem in sports does not recognise the place they have in helping athletes thrive. The CanMEDS Framework, developed by the Royal College of Physicians and Surgeons of Canada, identifies the roles and desired attributes physicians require to effectively meet the community's healthcare needs. Many of these roles are applicable to sports medicine to guide the care of our 'community' of athletes in the context of harassment and abuse (see figure 2). ${ }^{15}$

Given the assertion that sports medicine physicians have the responsibility to safeguard athletes from the health impacts of harassment and abuse and the alarming prevalence, it is apparent that there is an urgent need for action by sports medicine, both individually and as a collective group. We must 'be the change' to strive for a safe sporting environment free from harassment and abuse.

Twitter Margo Lynn Mountjoy @margo.mountjoy and Evert Verhagen @ evertverhagen

Contributors MLM: conception and design of the editorial, drafting, writing and revising of the manuscript. EV: conception and design of the editorial, editing and revising of the manuscript.
Funding The authors have not declared a specific grant for this research from any funding agency in the public, commercial or not-for-profit sectors.

Competing interests EV is Editor-in-Chief of BMJ Open Sports \& Exercise Medicine.

Patient consent for publication Not applicable.

Ethics approval This study does not involve human participants.

Provenance and peer review Not commissioned; externally peer reviewed.

Open access This is an open access article distributed in accordance with the Creative Commons Attribution Non Commercial (CC BY-NC 4.0) license, which permits others to distribute, remix, adapt, build upon this work non-commercially, and license their derivative works on different terms, provided the original work is properly cited, appropriate credit is given, any changes made indicated, and the use is non-commercial. See: http://creativecommons.org/licenses/by-nc/4.0/.

\section{ORCID iDs}

Margo Lynn Mountjoy http://orcid.org/0000-0001-8604-2014

Evert Verhagen http://orcid.org/0000-0001-9227-8234

\section{REFERENCES}

1 Mountjoy M, Brackenridge C, Arrington M. The IOC consensus statement: harassment and abuse (nonaccidental violence) in sport. Br J Sports Med 2016;50:1019-29.

2 Human Rights Watch. "I was hit so many times, I can't count.", 2020. Available: https://www.hrw.org/report/2020/07/20/i-was-hitso-many-times-i-cant-count/abuse-child-athletes-japan [Accessed 18 Dec 2021].

3 National Police Chiefs' Council. Operation Hydrant - football abuse statistics up to and including, 2018. Available: https://www. npcc.police.uk/NPCCBusinessAreas/OtherWorkAreas/OpHydrant/ FootballAbuseStats.aspx [Accessed 18 Dec 2021].

4 Longman J, Molina R. New York times. world Basketball chief steps aside amid sexual abuse investigation, 2021. Available: https://www. nytimes.com/2021/06/13/sports/olympics/fiba-basketball-malisexual-abuse.html [Accessed 18 Dec 2021].

5 Mountjoy M. 'Only by speaking out can we create lasting change': what can we learn from the Dr Larry Nassar tragedy? Br J Sports Med 2019;53:57-60. 
6 Alexander K, Stafford A, Lewis R. The experiences of children participating in organised sport in the UK. London: NSPCC, 2011.

7 Stafford A, Alexander K, Fry D. 'There was something that wasn't right because that was the only place I ever got treated like that': Children and young people's experiences of emotional harm in sport. Childhood 2015;22:121-37.

8 Vertommen T, Schipper-van Veldhoven N, Wouters K, et al. Interpersonal violence against children in sport in the Netherlands and Belgium. Child Abuse Negl 2016;51:223-36.

9 Gervis M, Dunn N. The emotional abuse of elite child athletes by their coaches. Child Abuse Rev 2004;13:215-23.

10 World Medical Association. Declaration in the Geneva. Available: https://www.wma.net/policies-post/wma-declaration-of-geneva/ [Accessed 18 Dec 2021].

11 International Olympic Committee. The Olympic movement medical code. in force as from 31 March, 2016. Available: https://stillmed.
olympic.org/media/Document\%20Library/OlympicOrg/IOC/

Who-We-Are/Commissions/Medical-and-Scientific-Commission/ Olympic-Movement-Medical-Code-31-03-2016.pdf [Accessed 18 Dec 2021].

12 Marks S, Mountjoy M, Marcus M. Sexual harassment and abuse in sport: the role of the team doctor. Br J Sports Med 2012;46:905-8.

13 Mountjoy M, Vertommen T, Denhollander R, et al. Effective engagement of survivors of harassment and abuse in sport in athlete safeguarding initiatives: a review and a conceptual framework. $\mathrm{Br} \mathrm{J}$ Sports Med 2022;56:232-8.

14 Humphries D, Jaques R, Dijkstra HP, et al. Delphi developed syllabus for the medical specialty of sport and exercise medicine: Part 2. Br J Sports Med 2021;55:81-3.

15 Royal College of Physicians and Surgeons of Canada. CanMEDS: better Standards, better physicians, better care, 2021. https://www. royalcollege.ca/rcsite/canmeds/canmeds-framework-e 